\title{
Review on inactivation of airborne viruses using non-thermal plasma technologies: from MS2 to coronavirus
}

\author{
Imen Assadi ${ }^{1}$ Ahlem Guesmi ${ }^{2} \cdot$ Oussama Baaloudj $^{3} \cdot$ Hichem Zeghioud $^{4} \cdot$ Walid Elfalleh $^{1} \cdot$ Naoufel Benhammadi $^{2}$. \\ Lotfi Khezami ${ }^{2}$. Aymen Amine Assadi ${ }^{5}$
}

Received: 1 September 2021 / Accepted: 8 November 2021 / Published online: 18 November 2021

(c) The Author(s), under exclusive licence to Springer-Verlag GmbH Germany, part of Springer Nature 2021

\begin{abstract}
Although several non-thermal plasmas (NTPs) technologies have been widely investigated in air treatment, very few studies have focused on the inactivation mechanism of viruses by NTPs. Due to its efficiency and environmental compatibility, non-thermal plasma could be considered a promising virus-inactivation technology. Plasma is a partly or fully ionized gas including some species (i.e., electrons, free radicals, ions, and neutral molecules) to oxidize pollutants or inactivate harmful organisms. Non-thermal plasmas are made using less energy and have an active electron at a much higher temperature than bulk gas molecules. This review describes NTPs for virus inactivation in indoor air. The different application processes of plasma for microorganism inactivation at both laboratory and pilot-scale was also reviewed This paper reports on recent advances in this exciting area of viral inactivation identifying applications and mechanisms of inactivation, and summarizing the results of the latest experiments in the literature. Moreover, special attention was paid to the mechanism of virus inactivation. Finally, the paper suggests research directions in the field of airborne virus inactivation using non-thermal plasma.
\end{abstract}

Keywords Non-thermal plasma $\cdot$ Virus inactivation $\cdot$ Indoor air $\cdot$ Best-advanced oxidation

\section{Introduction}

Viruses are part of the life history on our planet and the most abundant and diverse microbes. These species dwelled in the World for billions of years and infected all cell-based life forms organisms, i.e., from bacteria to humans, animals, and plants (Couch, 1981). Consequently, they are responsible for

Responsible Editor: Sami Rtimi

Aymen Amine Assadi

Aymen.Assadi@ensc-rennes.fr

1 Laboratoire Energie, Eau, Environnement Et Procèdes, ENIG, Université de Gabès, LR18ES356072 Gabès, Tunisia

2 Department of Chemistry, Imam Mohammad Ibn Saud Islamic University (IMSIU), P.O. Box 5701, 11432 Riyadh, Saudi Arabia

3 Laboratory of Reaction Engineering, USTHB, BP 32, 16111 Algiers, Algeria

4 Department of Process Engineering, Badji Mokhtar University, P.O. Box 12, 23000 Annaba, Algeria

5 University Rennes, ENSCR- 11 Allée de Beaulieu, 35708 Rennes, France numerous hospitalizations, animal diseases, deaths, and crop losses, leading to immense social, economic, and biological pressures (Filipić et al. 2020a). They have adapted to various climates and are now found in all environmental compartments, such as the air, where the risk of infectious respiratory diseases is higher than any other sources (Tregoning and Schwarze, 2010). A viral respiratory infection could be exposed to bacterial disease, thus duplicating the risk of death (Hament et al. 1999). Despite considerable public health efforts, epidemics of viral respiratory infections are still common (widespread) in healthy humans and can lead to the death of vulnerable people (Moriyama et al. 2020). In 2017 alone, the Global Burden of Disease study found that air pollution is a fatal source of nearly 5 million premature deaths (Xiao et al. 2020). Also, another study via the World Bank in 2007 found that air infection diseases kill 750,000 people annually in China (Chang, 2012).

Typically, viruses exist in the air at specific concentrations, which are not generally sufficient to cause disease in humans because the immune system of healthy humans prevents infections. However, the risk of human contamination rises significantly at higher infectious virus concentrations (Nikitin et al. 2014). Numerous epidemiological studies 
demonstrated that air transmissions via aerosols, large droplets, or direct contact with secretions lead to a substantial increase in human morbidity and mortality, making air the most significant vector of viral infection (Couch 1981; Martínez-Montelongo et al. 2020. Pollution of indoor and outdoor air has been identified as responsible for significant deleterious effects on human health and social and economic growth (Martínez-Montelongo et al. 2020). However, indoor air pollution is the primary concern as it is $2-5$ times more polluted than outside air pollution; in extreme cases, it can be over 100 times higher (Fang et al. 2016). Also, indoor environments often harbor potentially unsafe microorganisms (La Giuseppina et al. 2013).

Pandemics such as the COVID-19 established the necessity for indoor air cleaning and air purification techniques (Kim and Jang 2018) and replacing, completing, or updating existing conventional viral inactivation methods ( $\mathrm{Li}$ et al. 2020). Most decontamination processes commonly used for viral inactivation like photocatalysis $\left(\mathrm{TiO}_{2}+\mathrm{UVA}\right)$ and filtration do not have an effective disinfection ability against viruses and have substantial inconveniences (Zhang and Gamage, 2010). Indeed, the most applied technologies to control and remove airborne pathogens are the collection of bioaerosols on filters, such as porcine reproductive and respiratory syndrome (PRRS), high-efficiency particulate arrestance (HEPA), minimum efficiency reporting value (MERV) 14 and MERV 16 filters, UV germicidal irradiation (UVGI), atmospheric pressure non-thermal plasmas (APNTP), and cold atmospheric pressure plasma (CAPP). HEPA filtration has been experienced to be very effective in removing bioaerosols from airstreams. In contrast, MERV filters were exhibited to be the safer choice for both roof bolter and face drill.

Indeed, Farnsworth et al. showed the highest efficiency (i.e., $96.5 \pm 1.5 \%$ ) of the bacterial collection of Baccilus subtilis by HEPA filtration. Alonso et al. reassessed the impact of air filtration from commercial sow farms on the incidence of PRRSV introductions. They found that air filtration resulted in a reduction of approximately $80 \%$ of the risk with introducing the new PRRSv, thus highlighting the role of PRRSv in aerosol filtration of the air. Otherwise, using HEPA filters denotes several disadvantages, such as high filter replacement costs, and high-pressure drops and increased energy consumption to maintain the desired ventilation rate (Amissah (2005), Tellier (2006), Tellier (2009)).

Likewise, HEPA filters do not deactivate pathogens, hence the possibility of re-emitting more resilient pathogens into the ambient air during the filter replacement and disposal processes. Effective UVGI disinfection requires enough high illumination intensity, achieved via an association of several bulbs with suitable exposure times in a well-designed airing system. However, the application of UVGI in the disinfection of indoor air is limited through the necessity to avoid the harmful effects of UV on human and animal health. One of those drawbacks is contamination with by-products of disinfection with carcinogenic effects and environmental pollution ( $\mathrm{Su}$ et al. 2018). Unlike those chemical methods, NTPs, also named cold plasma (CP), entered the decontamination processes as a new, effective, clean solution for inactivating the virus (Lacombe et al. 2017). NTP is a complex mixture, consisting of a partially ionized gas containing high-energy photons (UV), free electrons, ions, radicals, and other reactive species (Assadi et al. 2015; Jia et al. 2015; Schmidt and Jo 2015; Jiang et al. 2017; Schiappacasse et al. 2020). It produces high-energy electrons which bump gas molecules, driving their dissociation, excitation, and ionization (Huang et al. 2018), thereby occurring many reactive oxidative species (ROS) including $\mathrm{OH}, \mathrm{O}_{2}{ }^{-}$, $\mathrm{O}_{3}$, and $\mathrm{H}_{2} \mathrm{O}_{2}$. This ROS may effectively inactivate viruses (Li et al. 2020), as well as nitrogen species (NS) which play vital roles in virus inactivation (Wang et al. 2016). It is one of the advanced oxidation technologies proven effective in biomedical fields, including decontamination and sterilization, due to its low cost, easy operation, and wide range of applications (Feng et al. 2020). It is also essentially clean and generates only small amounts of persistent chemical species (Moreau et al. 2008). Few papers report NTP as an antiviral treatment in the air, yet it shows great promise and has proven to inactivate many types of microorganisms such as airborne viruses (Gallagher et al. 2004; Scholtz et al. 2015). For instance, NTP inactivation of coronavirus (COVID-19) (Chen and Wirz, 2020), Newcastle disease virus (NDV) (Su et al. 2018), and avian influenza virus (AIV) (Wang et al. 2016) have been successful. Thus, strategies should continue to be developed to improve NTP-based technologies to battle viruses for humanity's long-term benefit.

This review focuses on NTPs for the inactivation of viruses in indoor air. It is an attractive advanced oxidation technology since it is a new, effective, clean solution for inactivating the virus and presents recent advances in the exciting area of virus's inactivation, identifying applications and inactivation mechanisms, and summarizing findings in the latest literature experiments. An enumeration of the worldwide problem related to airborne viruses is cited. The effect of key operating parameters on NTP plasma techniques used in the literature is developed.

\section{Viruses in indoor air}

The term "indoor" includes all enclosed spaces occupied by humans such as homes, offices, schools, workplaces, commercial units, airports, hospitals, other health facilities (Moreau et al. 2008). According to the Environmental Protection Agency (EPA), many people spend about $90 \%$ or more (i.e., most of their time indoors) (Chen et al. 2020). 
People spend more time at home than in any other indoor environment (Scholtz et al. 2015). Also, indoor air pollution is 2-5 times more polluted than outside air pollution. In extreme cases, it can be over 100 times higher (Chen et al. 2020) because of the various sources of indoor chemical pollution like formaldehyde from wood and biologic pollution (Anderson and Albert 1998). Besides, a study estimated the total concentrations of viruses in indoor air and found about $10^{5}$ particles $\mathrm{m}^{-3}$, which is an extremely high concentration (Chen et al. 2020). Environmental Protection Agency (EPA) ranks indoor air pollution as one of the top 5 environmental hazards and health threats, improving indoor air quality (IAQ) to reduce sickness. IAQ is the field of applied science or analysis of indoor air conditions that includes the viral, microbiological, and chemical-physical composition in the air in and around buildings (Maisey 2012). The definition of acceptable IAQ is provided by standard ISO 16000 "air in confined environments" in particular ISO 16814: air in an internal building which does not displease the vast majority of people inside to ensure them healthy conditions and is unlikely to contain pollutants leading to a risk to exposure to health (Prussin et al. 2015). The World Health Organization (WHO) stated that IAQ is essential for preserving human health.

Indoor air quality has a significant impact on human health status. Therefore, WHO concluded that it is the human right to breathe healthy indoor air. It is, therefore, the responsibility of all those involved to ensure acceptable indoor air quality. It becomes just like an invisible killer (World Health Organization 2000). According to China Standardization Association, 68\% of illnesses are caused by poor indoor air quality (Vohra et al. 2006). In addition, some authors reported that higher disease and mortality rates are linked to air pollution and poor indoor air quality [46]. Yet, exposure to air pollutants can increase the susceptibility and severity of respiratory viruses in indoor air. Most upper respiratory infections (URIs) like cold, pneumonia, pharyngitis, laryngitis, and epiglottitis are caused by over 200 different viruses, including influenza viruses, rhinoviruses, coronaviruses, adenoviruses, respiratory syncytial viruses, and enteroviruses (US EPA, 2006). Recently, other viruses emerged at the end of 2019, such as SARS-CoV-2, killing millions of people worldwide, thus demonstrating the dangerousness of infectious respiratory diseases. Due to their high airborne transmission ability, inhaling these viruses can cause or worsen disease in humans (Rahmani et al. 2020), especially in crowded and poorly ventilated environments. They are responsible for most upper respiratory infections (Cimbala 2003). Many of the illnesses associated with SARS-CoV-2 that increase the risk of death are those caused by long-term exposure to air pollution (Xiao et al. 2020). Indoor virus species is one of the most common environmental health problems reported today (Table1). Exposure to aerosols generated by coughing and sneezing from infected individuals or in contact with droplet-contaminated surfaces (plastic, metal, and clothing) has been widely viewed as the dominant mode of transmission of respiratory pathogens (virus and bacteria). In addition, it has been validated that airborne transmission is traditionally defined as involving the inhalation of infectious aerosols primarily at a distance of less than 1 to $2 \mathrm{~m}$ from the individual carrying the virus. Such transmission has been reported, and considered as the main route of virus transmission. However, recently airborne transmission of many respiratory viruses has been validated, such as coronavirus (SARS-CoV), Middle East respiratory syndrome (MERS)-CoV, and influenza virus (Wang et al. 2021).

Viruses such as the coronavirus (i.e., SARS-CoV-2) are intracellular parasites that are very small in the range of 20 to $400 \mathrm{~nm}$. These viruses are resistant to indoor air for a long time, especially in crowded or small environments. Inhaling these viruses causes illness or worsens infections of the upper respiratory tract (Prussin et al. 2015). In the event of a viral pandemic, many countries implement containment measures to prevent the spread of the virus. Still, this practice induces poor indoor air quality, which will lead to other health problems. Indoor air in enclosed public spaces is at increased risk of viruses because IAQ regulations are not adapted to current scientific research. So, viruses can spread through the air and even easily enter indoor air (World Health Organization 2000). Once locked in, even simple actions like talking, sneezing, and coughing that cause small virus-filled droplets of saliva to spread through the air and onto surfaces, especially on the hands (Alshraiedeh et al. 2013). Viral infection can spread from person to person, making humans a significant source of indoor viral infection. Pets are also a foremost source of indoor air contamination. Viruses can infect all living cell-based organisms, from bacteria to humans, animals, and plants (Filipić et al. 2020a, b).

Indoor air humidity is a major determinant of indoor air quality (Sakudo et al. 2014). It plays an important role in viral infections by promoting the survival rate of viruses and an increased risk of respiratory infections and allergic diseases (Aboubakr et al. 2018). Several studies demonstrated that indoor temperature and humidity (generally between 19 and $26^{\circ} \mathrm{C}$ and $50-60 \% \mathrm{RH}$ ) positively affect the spread of infections and the vulnerability of individuals to viruses (Liang et al. 2020).

Pandemics such as COVID-19 require implementing new indoor air purification techniques (Kim and Jang, 2018), replacing, combining, or improving existing conventional viral inactivation methods. Conventional methods for viral inactivation, such as chlorine disinfection, do not have an effective disinfection ability against viruses (Ashraf et al. 2013). Unlike those methods, NTPs can deal with both 


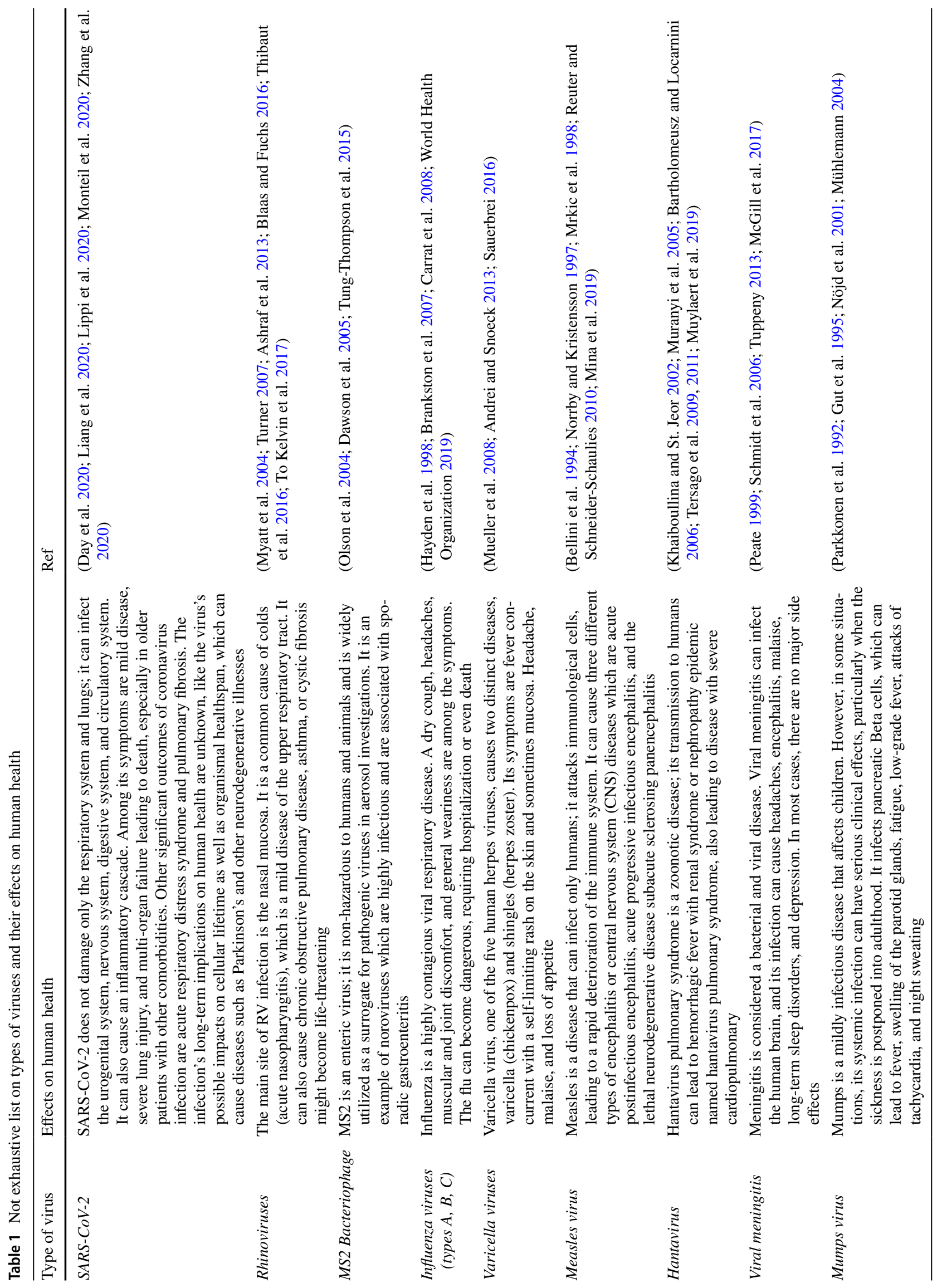


transport and infectivity of airborne viruses by filtration and interact with interactive plasma species (Xia et al. 2019).

\section{Parameters controlling viruses' inactivation performance}

Several parameters remain essential in the non-thermal discharge viruses' inactivation, such as virus concentration, input power, air humidity, air composition, reactor design, and type of discharge. It is also worth noting the oxygen concentration.

\section{The effect of the viruses' concentration}

The virus concentration effect in the non-thermal discharge viruses' inactivation was reported in several studies (Chen et al. 2010). Indeed, Puligundla and Mok (Puligundla and Mok, 2016) revealed a reduction of at least 4 to $6 \log 10$ of two bacteriophages at concentrations of $10^{6} \mathrm{PFU} / \mathrm{mL}^{-1}$ after 10 min of exposure to NTP.

After a couple of seconds of discharge treatment, the number of infectious phages decreased quickly, and 6 orders of magnitude inactivation were achieved. On the other hand, the virus concentrations used in NTPs ranked from $1 \times 10^{6}$

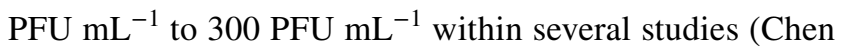
et al. 2010; Puligundla and Mok 2016; Jiang et al. 2017; Filipić et al. 2020a). We noted $10^{5} \mathrm{TCID}_{50} / \mathrm{mL}$ of bacteriophage MS2, matching $69 \times 10^{6} \mathrm{PFU} / \mathrm{mL}$ according to Xia et al. (Xia et al. 2019) study, while that of Venezia et al. (Alshraiedeh et al. 2013) denoted $10^{9} \mathrm{PFU} / \mathrm{mL}$.

Thus, some works reported a proportional relationship between virus concentration and the inactivation performance with non-thermal plasma: the inactivation yield of virus decrease with very polluted indoor air. This finding might be due to the higher virus concentration, and the step limitation is the reaction between reactive species and viruses (Lee et al. 2021).

\section{Input power}

Input power is an important factor in influencing virus removal in NTP reactors. In fact, virus elimination measurements are a function of input power (Mustafa et al. 2018). Several previous studies demonstrated that the removal efficiencies of harmful airborne components increase with the NTP input power (Shimizu and Oda 1999; An et al. 2011; Pinard et al, 2019; Xia et al. 2019). It is well known that the power of the plasma is proportional to the voltage applied in the discharge zone. Indeed, the increase in electric power pleads in favor of having an increase in electric current in the vicinity of the virus. Since the virus is in direct contact with the plasma, the exposure of the virus to species produced by short-lived plasma, including electrons, ions, radicals, and UV rays, is significantly higher compared to other treatment modalities. Likewise, the virus will also be subjected to high electric fields at the plasma-surface interface. All of these active species $\left(\mathrm{OH}^{\circ}, \mathrm{O}^{\circ}, \mathrm{O}_{3}, \mathrm{e}^{-}\right)$ensure the inactivation of the virus (Mohamed et al. 2021).

Indeed, Xia et al. (Xia et al. 2019) examined viruses' inactivation through NTP coupled with a packed-bed dielectric barrier discharge plasma. After NTP treatment, the results revealed a higher inactivation of phage MS2 with a rise in the applied voltage up to $30 \mathrm{kV}$ (Alshraiedeh et al. 2013).

\section{Air humidity}

The non-thermal discharge viruses' inactivation can be affected by many environmental factors such as air humidity versus the different reactors. For instance, Cutler et al. (Cutler et al. 2012) demonstrated that for any temperature, the rate of the inactivation of the airborne porcine reproductive and respiratory syndrome (PRRS) was highest at a relative humidity between 25 and $79 \%$ and lowest at relative humidity $>80 \%$. Likewise, Xia et al. (Xia et al. 2020) found $98.6 \%$ as the PRRSv inactivation efficiency with $38 \%$ of relative humidity under $20-\mathrm{kV}$ voltage supplied to the packed-bed NTP reactor. However, some authors investigated the spread of relative humidity $(\mathrm{RH})$ within the NTP reactor, and they found that the RH evolved to reach $60 \%$ at a steady state in $30 \mathrm{~min}$ (Xia et al. 2019). This result obtained with the NTP reactor corroborates that of Cutler et al. (Cutler et al. 2012) in the case of the PRRS virus, regarding the RH effect on the reactor efficiency. On the other hand, other studies have reported that the relative humidity of the PRRS virus depends on the viral envelopes (Elazhary and Derbyshire, 1979). Viruses with lipoprotein envelopes tend to be more stable at lower relative humidity and non-enveloped viruses more stable at higher relative humidity. Overall, relative humidity plays an important role in the different reactors' yields. The divergence in the resulting level is due to the difference in generating the plasma process, the residence time, reactor configuration, etc.

\section{Reactor for the inactivation of viral aerosols}

Over the past 20 years, several technologies have been devised for the inactivation of non-thermal discharge viruses (Jacobs et al. 2010; Alshraiedeh et al. 2013; Sakudo et al. 2014).

Recently, some studies examined microbial inactivation, sterilization, and disinfection using APNTP within a field of biomedical application (Fridman et al. 2008). APNTP applying possesses potential favor over standard chemical 
sterilants and disinfectants (Fig. 1). These include the design's simplicity and operation. It uses non-toxic gases with the absence of toxic residues and the production of a

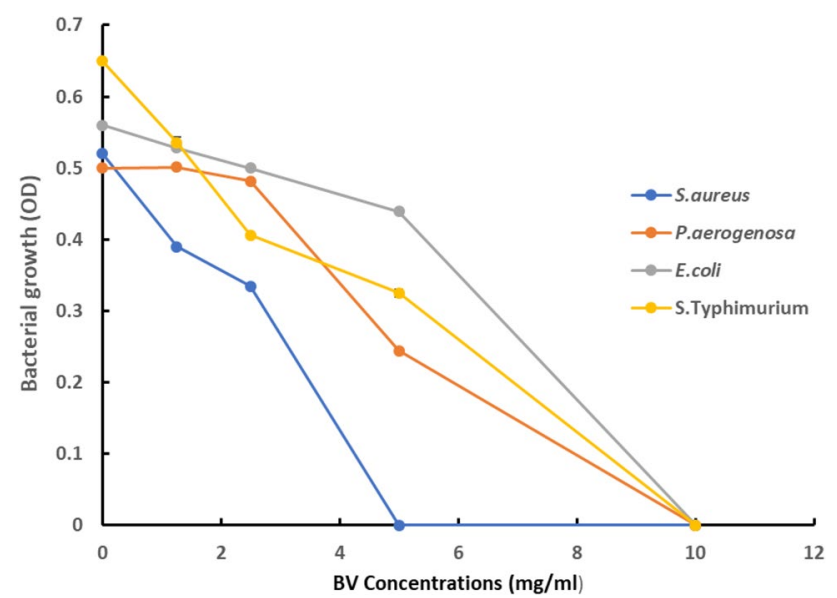

Fig. 1 Schematic of the DBD packed-bed reactor for the inactivation of viral aerosols (Michielsen et al. 2017; Uytdenhouwen et al. 2018) large amount of various microbicidal active species, including chemically reactive species (Yardimci and Setlow, 2010; Nayak et al. 2018) (Table 2).

\section{Combined system for virus disinfection}

Several works have been reported on conventional techniques for viruses and bacterial inactivation treatment, whether physical or chemical (Table 3). Some technologies have been combined with different forms of electric discharge plasma or other decontamination processes to deal with various pathogenic microorganisms' high levels of contamination to improve inactivation efficiency (Bourke et al. 2018; Kordová et al. 2018; Rtimi and Kiwi, 2021).

In recent years, current trends have been moving towards the coupling of plasma and nanomaterials with dimensions in the order of a nanometer (i.e., 1 to $100 \mathrm{~nm}$ ). This process has been well confirmed with the inactivation effects of nanomaterials on various viruses due to a large specific surface area, including the generation of ROS (Abidi et al.

Table 2 plasma reactor configuration for viruses and bacterial inactivation treatment for some types of the virus with reactive species.

\begin{tabular}{|c|c|c|c|c|}
\hline Virus & $\begin{array}{l}\text { Reactive species } \\
\text { responsible for the } \\
\text { inactivation }\end{array}$ & NTP reactor configuration & Mode of inactivation & References \\
\hline SARS-CoV-2 & RONS & $\begin{array}{l}\text { Cylindrical cold atmos- } \\
\text { pheric plasma reactor } \\
\text { (CCAPR) }\end{array}$ & DNA/RNA degradation & (Chen et al. 2020) \\
\hline \multirow[t]{2}{*}{ MS2 bacteriophage } & $\mathrm{O}$ & \multirow[t]{2}{*}{$\begin{array}{l}\text { Tubular atmospheric pres- } \\
\text { sure cold plasma (TAPCP) }\end{array}$} & $\begin{array}{l}\text { Both protein and DNA/RNA } \\
\text { degradation }\end{array}$ & (Wu et al. 2015) \\
\hline & $\mathrm{O}_{3}$ & & NA & (Xia et al. 2019) \\
\hline Adenovirus & $\begin{array}{l}\mathrm{H}_{2} \mathrm{O}_{2} \\
\mathrm{O}_{3}\end{array}$ & $\begin{array}{l}\text { surface micro-discharge } \\
\text { (SMD) plasma electrode } \\
\text { using an insulator plate } \\
\text { made of } \mathrm{Al} 2 \mathrm{O} 3\end{array}$ & $\begin{array}{l}\text { DNA/RNA degradation } \\
\text { NA }\end{array}$ & $\begin{array}{l}\text { (Sakudo et al. 2016) } \\
\text { (Zimmermann et al. 2011) }\end{array}$ \\
\hline $\mathrm{T4}, \Phi 174$, and MS2 & $\mathrm{O}_{2}, \mathrm{NO}_{2}$, and $\mathrm{ONOO}^{-}$ & $\begin{array}{l}\text { Mesh electrode with a } \\
\text { planar configuration }\end{array}$ & $\begin{array}{l}\text { Both protein and DNA/RNA } \\
\text { degradation }\end{array}$ & (Guo et al. 2018) \\
\hline \multirow[t]{4}{*}{ Feline calicivirus (FCV) } & $\mathrm{O}$ and $\mathrm{ONOOH}$ & \multirow[t]{4}{*}{ Tubular reactor plasma } & Protein degradation & (Aboubakr et al. 2016) \\
\hline & $\mathrm{O}_{2}$ and $\mathrm{ONOO}^{-}$ & & DNA/RNA degradation & (Yamashiro et al. 2018) \\
\hline & $\mathrm{O}_{2}$ and $\mathrm{O}_{3}$ & & $\begin{array}{l}\text { Both protein and RNA } \\
\text { degradation }\end{array}$ & (Aboubakr et al. 2018) \\
\hline & $\mathrm{NO}_{\mathrm{x}}$ and $\mathrm{O}_{3}$ & & NA & (Nayak et al. 2018) \\
\hline $\begin{array}{l}\text { Respiratory syncytial virus } \\
\text { (RSV) }\end{array}$ & $\mathrm{H}_{2} \mathrm{O}_{2}$ & Tubular NTP reactor & DNA/RNA degradation & (Sakudo et al. 2017) \\
\hline HIV-1 & $\mathrm{O}_{2}^{+}, \mathrm{O}, \mathrm{NO}$, and $\mathrm{N}_{2}$ & $\begin{array}{l}\text { Cylindrical cold atmos- } \\
\text { pheric plasma reactor } \\
\text { (CCAPR) }\end{array}$ & DNA/RNA degradation & (Volotskova et al. 2016) \\
\hline \multirow[t]{2}{*}{$\begin{array}{l}\text { Newcastle disease virus } \\
\text { (NDV) }\end{array}$} & $\mathrm{H}_{2} \mathrm{O}_{2}, \mathrm{OH}^{\bullet}$, and $\mathrm{NO}_{\mathrm{x}}$ & \multirow{4}{*}{$\begin{array}{l}\text { Magnetically rotated gliding } \\
\text { arc \& DBD plasma planar } \\
\text { reactor }\end{array}$} & $\begin{array}{l}\text { Both protein and DNA/RNA } \\
\text { degradation }\end{array}$ & (Su et al. 2018) \\
\hline & RONS & & RNA degradation & (Schiappacasse et al. 2020) \\
\hline Influenza viruses & $\mathrm{H}_{2} \mathrm{O}_{2}$ & & $\begin{array}{l}\text { Both protein and RNA } \\
\text { degradation }\end{array}$ & (Sakudo et al. 2014) \\
\hline Influenza A & $\mathrm{OH}$ and $\mathrm{O}_{3}$ & & NA & (Gallagher et al. 2004) \\
\hline
\end{tabular}




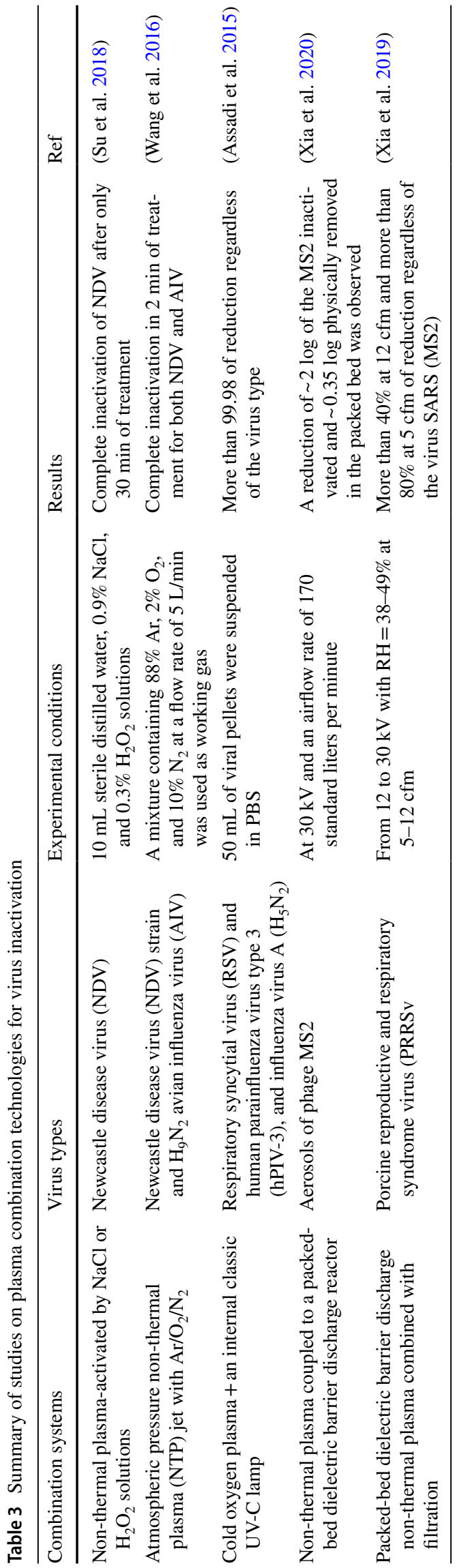

$2019,2020)$. The effects resulting from the combination between the plasma in the catalytic oxidation, the photothermal influences, and the release of metal ions allow having a synergistic impact on the antiviral performances $(\mathrm{Li}$ et al. 2021). Therefore, there is a comprehensive promise in developing antiviral nanomaterials and using them to air purifier filters, building ventilation systems, antiviral fabrics, and antiviral spray agents, which assists in controlling the spread of viruses through aerosols.

\section{Mechanism of viral inactivation by the non-thermal discharge}

Non-thermal plasma constitutes one of the recent processes of advanced oxidation processes (AOPs). This technology allows the formation of heavy mixtures and lighting from the excitation of gases by electric discharge. Probably, the effectiveness of NTPs is because they combine both physical and chemical mechanisms (Ateia et al. 2020). However, these coupled techniques generate highly reactive oxidizing components, free radicals, and ions (e.g., ozone, hydrogen peroxide, hydroxyl, and superoxide radicals) in aqueous solutions under UV irradiation (Wang et al. 2018). Figure 1 shows a schematic of the action of NTP of viral inactivation by the non-thermal discharge. The generation of reactive oxygen species (ROS) and/or reactive nitrogen species (RNS) is the main feature of NTP that contributes to virus inactivation. The main target of ROS/RNS is virus capsid, genome, protein, and glycoprotein. The short lifespan of ROS or RNS makes the identification and assessment of ROS/RNS a challenging task. Furthermore, the experimental conditions (the gas used for the NTP generation, the matrix, the virus treated...etc.) play a crucial role in the generation of particular ROS/RNS.

The most crucial component for evaluating virus inactivation is the degradation of the capsid. The viral envelope or capsid is the first contact point with the host cell. For an efficient recognition of a virus by the cell receptors, their outer structure must be intact.

The increased oxidative force of NTP can denature the virus and genome structure by affecting both proteins and nucleic acids. Conformational disruption of the capsid proteins caused by ROS/RNS can result in loss of viral infectivity due to the virus's disruption binding to receptors on the host cell membrane (Filipić et al. 2020b).

In addition to capsid and nucleic acid, further damage could be seen in lipid components from the envelope the virus influenza A (Sakudo et al. 2014). Particularly in the case of bacteriophage $\lambda$ (Yasuda et al. 2010) and FCV (Aboubakr et al. 2018), it has been proved that the main mode of NCP inactivation is the degradation of the capsid proteins proceeding with the degradation of nucleic acids (Fig. 2). However, in several 
studies, it was impossible to determine which degradation path contributed more to the decay in viral infectivity (Filipić et al. 2020b).

\section{Chemical processes' reactions}

It is worthy to note that in humid air, electrons with very high kinetic energy and could react with water vapor to occur reactive species. Then, some reactive chemical species (i.e., $\mathrm{H}_{2} \mathrm{O}_{2}$, $\left.\mathrm{O}_{3}, \mathrm{O}_{2}^{-*}, \mathrm{OH}\right)$ also react by attacking the high-energy electron (Wang et al. 2018). In fact, electrons energy generated through the electrical discharge plasma process can outdo the decay or ionization energy of water molecules (Joshi et al. 1995; Wang et al. 2008). Through electron collisions, the dissociation of water molecules in the air could form $\mathrm{H}, \mathrm{OH}$, and other hydrated cations as follows (Hong and Zeng, 2002; Wang et al. 2008):

$\mathrm{e}^{-*}+\mathrm{H}_{2} \mathrm{O} \rightarrow \mathrm{OH}+\mathrm{H}+\mathrm{e}$

$\mathrm{e}^{-*}+\mathrm{H}_{2} \mathrm{O} \rightarrow \mathrm{H}_{2} \mathrm{O}^{+}+2 \mathrm{e}^{-}$

$\mathrm{H}_{2} \mathrm{O}^{+}+\mathrm{H}_{2} \mathrm{O} \rightarrow \mathrm{H}_{3} \mathrm{O}^{+}+\mathrm{OH}$

where * denoted high-energy electron state. These formed radicals could react together or recombine with other reactive species, as presented in the following reactions (Zhou et al. 2016):

$\mathrm{H}+\mathrm{H} \rightarrow \mathrm{H}_{2}$

$\mathrm{OH}+\mathrm{OH} \rightarrow \mathrm{H}_{2} \mathrm{O}_{2}$

$\mathrm{OH}+\mathrm{H} \rightarrow \mathrm{H}_{2} \mathrm{O}$

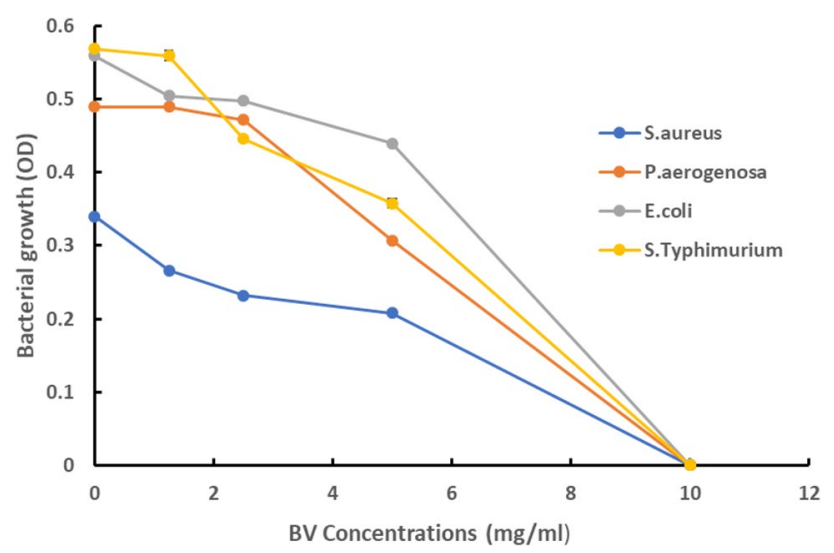

Fig. 2 A schematic of the action of NTP of viral inactivation by the non-thermal discharge
$\mathrm{e}^{-}+\mathrm{H}_{2} \mathrm{O}_{2} \rightarrow \mathrm{OH}+\mathrm{OH}^{-}$

$\mathrm{O}_{2}+\mathrm{e}^{-} \rightarrow \mathrm{e}^{-}+2 \mathrm{O}$

Despite the free radicals' generation for virus degradation in NTPs, ozone $\left(\mathrm{O}_{3}\right)$ reactions also occur. Once 'O is formed (i.e., Eq. 8) via high-energy electronic attack, it could react with $\mathrm{O}_{2}$ and organic matter (M) to generate $\mathrm{O}_{3}$, as shown in the reaction (9) (Wang et al. 2018).

$\mathrm{O}+\mathrm{O}_{2}+\mathrm{M} \rightarrow \mathrm{O}_{3}+\mathrm{M}$

where $\mathrm{M}$ is organic matter, $\mathrm{O}_{3}$ could react with various compounds through direct $\mathrm{O}_{3}$ and indirect $\mathrm{O}_{3}$ oxidation reactions. In previous studies, also it was found that the ozone produced by plasma was not the main contributor to the inactivation effect; nevertheless, it is involved in the inactivation (Morrison et al. 2021). In fact, Morisson and her co-workers (Morisson et al. 2021) showed that ozone disinfection had demonstrated high efficacy against enveloped and non-enveloped viruses, including viruses similar in morphology to SARS-CoV-2.

\section{Physical processes' reactions}

The physical processes of the inactivation effect in nonthermal plasma can occur via UV irradiation (Sun et al. 2005; Wang et al. 2006; Tang et al. 2018), shock waves (Šunka 2001; Ghernaout and Elboughdiri, 2020), and electric field effects (Schoenbach et al. 1997, 2000). Indeed, the UV irradiation from gas-phase discharges is weaker than that from the liquid phase. The types of UV irradiation from gas-phase discharges at atmospheric pressure are generally within the UVA and UVB regions, with wavelengths ranging of 320-400 $\mathrm{nm}$ and $280-320 \mathrm{~nm}$, respectively. Matsumoto et al. (Matsumoto et al. 1992) reported that UV irradiation performed an essential part in bacteria inactivation. Moreover, UV irradiation has also been used in the gas-phase discharge plasma process (Xue et al. 2008).

In the absence of electric discharge, the electric field is an alternative method for inactivating cells and processing food products. Previous research reported that a potent electric field could inactivate the microorganisms and biofilm bacteria on the walls of cooling and drinking water pipes (Schoenbach et al. 2000). 


\section{Conclusions and outlook}

Over the past decades, interest in applying non-thermal plasma technology for virus inactivation within indoor air has considerably increased. In this review paper, commonly used non-thermal plasma reactors and their effectiveness in virus inactivation have been extensively exhibited. Moreover, the inactivation mechanisms and the factors controlling these reactors, such as virus concentration, input power, air humidity, air composition, and reactor design, have also earned attention.

Notwithstanding the determining factors in non-thermal plasma processes, the production and evolution of active species and the physical effects of viral inactivation must be further investigated to explain the mechanisms of plasma oxidation and optimize the oxidation non-thermal plasmas process. Furthermore, investigations should be performed on the impact of target properties, including volatility, hydrophobic/hydrophilic nature, stability, and diffusivity. However, non-thermal plasma can be combined with other technologies involving catalysts like carbonaceous materials, metal oxides, and metal ions. The mechanism of interaction between viral inactivation and catalysts needs to be well studied. Well-mastered nonthermal plasma could be a promising alternative to face these waves of COVID-19 infections.

Author contribution Imen ASSADI: validation, investigation, visualization, resources, writing-original draft, writing-review \& editing.

Oussama BAALOUDJ and Hichem ZEGHIOUD: methodology, validation, writing-original draft, writing-review \& editing.

Walid ELFALLEH and Naoufel BENHAMMADI: conceptualization, validation, writing-original draft, writing-review \& editing, visualization, supervision.

Ahlem GUESMI: methodology, resources, supervision.

Lotfi KHEZAMI: methodology, validation, investigation, review \& editing.

Aymen ASSADI: conceptualization, methodology, supervision.

Funding This research was supported by the Deanship of Scientific Research, Imam Mohammad Ibn Saud Islamic University (IMSIU), Saudi Arabia, Grant No. (21-13-18-035).

Data availability The datasets used and/or analyzed during the current study are available from the corresponding author on reasonable request.

\section{Declarations}

Ethics approval and consent to participate Not applicable.

Consent for publication: Not applicable.

Competing interests The authors declare no competing interests.

\section{References}

Abidi M, Assadi AA, Bouzaza A et al (2019) Photocatalytic indoor / outdoor air treatment and bacterial inactivation on $\mathrm{CuxO} / \mathrm{TiO} 2$ prepared by HiPIMS on polyester cloth under low intensity visible light Applied Catalysis B : Environmental photocatalytic indoor / outdoor air treatment and bacterial. Appl Catal B Environ 259:118074. https://doi.org/10.1016/j.apcatb.2019.118074

Abidi M, Hajjaji A, Bouzaza A et al (2020) Simultaneous removal of bacteria and volatile organic compounds on $\mathrm{Cu} 2 \mathrm{O}$ - NPs decorated $\mathrm{TiO} 2$ nanotubes competition effect and kinetic studies Journal of Photochemistry \& Photobiology A : Chemistry Simultaneous removal of bacteria and volatile organic compo. J Photochem Photobiol A Chem 400:112722. https://doi.org/10.1016/j.jphot ochem.2020.112722

Aboubakr HA, Gangal U, Youssef MM et al (2016) Inactivation of virus in solution by cold atmospheric pressure plasma: identification of chemical inactivation pathways. J Phys D Appl Phys 49:45. https://doi.org/10.1088/0022-3727/49/20/204001

Aboubakr HA, Mor SK, Higgins LA et al (2018) Cold argon-oxygen plasma species oxidize and disintegrate capsid protein of feline calicivirus. PLoS ONE 13:1-24. https://doi.org/10.1371/journ al.pone. 0194618

Alshraiedeh NH, Alkawareek MY, Gorman SP et al (2013) Atmospheric pressure, nonthermal plasma inactivation of MS2 bacteriophage: effect of oxygen concentration on virucidal activity. J Appl Microbiol 115:1420-1426. https://doi.org/10.1111/jam. 12331

Amissah P (2005) Indoor air quality: combining air humidity with construction moisture. Environ Pollut 449:461-469. https://doi. org/10.1016/j.scitotenv.2012.12.043

An G, Sun Y, Zhu T, Yan X (2011) Degradation of phenol in mists by a non-thermal plasma reactor. Chemosphere 84:1296-1300. https://doi.org/10.1016/j.chemosphere.2011.05.007

Anderson EL, Albert RE (1998) Risk assessment and indoor air quality

Andrei G, Snoeck R (2013) Advances in the treatment of varicellazoster virus infections, 1st edn. Copyright (C) 2013 Elsevier Inc. All rights reserved.

Ashraf S, Brockman-Schneider R, Bochkov YA et al (2013) Biological characteristics and propagation of human rhinovirus-C in differentiated sinus epithelial cells. Virology 436:143-149. https:// doi.org/10.1016/j.virol.2012.11.002

Assadi AA, Bouzaza A, Wolbert D, et al (2015) Study of synergetic effect by surface discharge plasma / $\mathrm{TiO} 2$ combination for indoor air treatment : sequential and continuous configurations at pilot scale to cite this version : HAL Id : hal-01158449

Ateia M, Alalm MG, Awfa D et al (2020) Modeling the degradation and disinfection of water pollutants by photocatalysts and composites: a critical review. Sci Total Environ 698:134197. https:// doi.org/10.1016/j.scitotenv.2019.134197

Australia Building Codes Board (2018) Handbook: indoor air quality

Bartholomeusz A, Locarnini S (2006) Associated with antiviral therapy. Antivir Ther 55:52-55. https://doi.org/10.1002/jmv

Bellini WJ, Rota JS, Rota PA (1994) Virology of measles virus. J Infect Dis 170:S15-S23. https://doi.org/10.1093/infdis/170. Supplement_1.S15

Blaas D, Fuchs R (2016) Mechanism of human rhinovirus infections. Mol Cell Pediatr 3:16-19. https://doi.org/10.1186/ s40348-016-0049-3

Bourke P, Ziuzina D, Boehm D et al (2018) The potential of cold plasma for safe and sustainable food production. Trends Biotechnol 36:615-626. https://doi.org/10.1016/j.tibtech.2017.11.001

Brankston G, Gitterman L, Hirji Z et al (2007) Transmission of influenza A in human beings. Lancet Infect Dis 7:257-265. https:// doi.org/10.1016/S1473-3099(07)70029-4 
Carrat F, Vergu E, Ferguson NM et al (2008) Time lines of infection and disease in human influenza: a review of volunteer challenge studies. Am J Epidemiol 167:775-785. https://doi.org/10.1093/ aje/kwm375

Chang Y (2012) China needs a tighter PM2.5 limit and a change in priorities. Environ Sci Technol 46:7069-7070. https://doi.org/ 10.1021/es3022705

Chen CY, Wu LC, Chen HY, Chung YC (2010) Inactivation of staphylococcus aureus and escherichia coli in water using photocatalysis with fixed TiO2. Water Air Soil Pollut 212:231-238. https:// doi.org/10.1007/s11270-010-0335-y

Chen Z, Garcia G, Arumugaswami V, Wirz RE (2020) Cold atmospheric plasma for SARS-CoV-2 inactivation. Phys Fluids 32https://doi.org/10.1063/5.0031332

Chen Z, Wirz RE (2020) Cold atmospheric plasma for COVID-19. Preprints 1-7. https://doi.org/10.20944/preprints202004.0126.v1

Cimbala JM (2003) Indoor air quality engineering environmental health and control of indoor pollutants (Drugs \& the Pharmaceutical Sciences)

Couch RB (1981) Viruses and indoor air pollution. Bull New York Acad Med J Urban Heal 57:907-921

Cutler TD, Wang C, Hoff SJ, Zimmerman JJ (2012) Effect of temperature and relative humidity on ultraviolet (UV 254) inactivation of airborne porcine respiratory and reproductive syndrome virus. Vet Microbiol 159:47-52. https://doi.org/10.1016/j.vetmic.2012. 03.044

Dawson DJ, Paish A, Staffell LM et al (2005) Survival of viruses on fresh produce, using MS2 as a surrogate for norovirus. J Appl Microbiol 98:203-209. https://doi.org/10.1111/j.1365-2672. 2004.02439.x

Day T, Gandon S, Lion S, Otto SP (2020) On the evolutionary epidemiology of SARS-CoV-2. Curr Biol 30:R849-R857. https://doi. org/10.1016/j.cub.2020.06.031

Elazhary MA, Derbyshire JB (1979) Effect of temperature, relative humidity and medium on the aerosol stability of infectious bovine rhinotracheitis virus. Can J Comp Med 43:158-167

Fang B, Xu Q, Park T, Zhang M (2016) AirSense: an intelligent homebased sensing system for indoor air quality analytics. UbiComp 2016 - Proc 2016 ACM Int Jt Conf Pervasive Ubiquitous Comput 109-119. https://doi.org/10.1145/2971648.2971720

Feng X, Chen C, He C et al (2020) Non-thermal plasma coupled with MOF-74 derived Mn-Co-Ni-O porous composite oxide for toluene efficient degradation. J Hazard Mater 383:121143. https:// doi.org/10.1016/j.jhazmat.2019.121143

Filipić A, Gutierrez-Aguirre I, Primc G et al (2020a) Cold plasma, a new hope in the field of virus inactivation. Trends Biotechnol. https://doi.org/10.1016/j.tibtech.2020.04.003

Filipić A, Gutierrez-Aguirre I, Primc G, et al (2020b) Cold plasma, a new hope in the field of virus inactivation. Trends Biotechnol xx:1-14. https://doi.org/10.1016/j.tibtech.2020.04.003

Fridman G, Friedman G, Gutsol A et al (2008) Applied plasma medicine. Plasma Process Polym 5:503-533. https://doi.org/10.1002/ ppap. 200700154

Gallagher MJ, Gutsol A, Fridman A, et al (2004) Non-thermal plasma applications in air sterilization. IEEE Int Conf Plasma Sci 198https://doi.org/10.1109/plasma.2004.1339779

Ghernaout D, Elboughdiri N (2020) Disinfecting water: plasma discharge for removing coronaviruses. Oalib 07:1-29. https://doi. org/10.4236/oalib.1106314

Giuseppina La Rosa, Marta Fratini SDL, Muscill MI and M (2013) Viral infections acquired indoors through airborne, droplet or contact transmission. Ann Ist Super Sanità 124-132https://doi. org/10.4415/ANN_13_02_03

Guo L, Xu R, Gou L et al (2018) Mechanism of virus inactivation by cold atmospheric-pressure plasma and plasma-activated water.
Appl Env Microbiol 84:1-10. https://doi.org/10.1128/AEM. 00726-18

Gut J-P, Lablache C, Behr S, Kirn A (1995) Symptomatic mumps virus reinfections. J Med Virol 45:17-23. https://doi.org/10.1002/jmv. 1890450104

Hament JM, Kimpen JLL, Fleer A, Wolfs TFW (1999) Respiratory viral infection predisposing for bacterial disease: a concise review. FEMS Immunol Med Microbiol 26:189-195. https:// doi.org/10.1016/S0928-8244(99)00159-5

Hayden FG, Fritz RS, Lobo MC et al (1998) Local and systemic cytokine responses during experimental human influenza A virus infection. Relation to symptom formation and host defense. J Clin Invest 101:643-649. https://doi.org/10.1172/JCI1355

Hong PKA, Zeng Y (2002) Degradation of pentachlorophenol by ozonation and biodegradability of intermediates. Water Res 36:4243-4254. https://doi.org/10.1016/S0043-1354(02)00144-6

Huang M, Zhuang H, Wang J et al (2018) Inactivation kinetics of Salmonella typhimurium and Staphylococcus aureus in different media by dielectric barrier discharge non-thermal plasma. Appl Sci 8:1-15. https://doi.org/10.3390/app8112087

Jacobs AC, Hermann JR, Muñoz-Zanzi C et al (2010) Stability of porcine reproductive and respiratory syndrome virus at ambient temperatures. J Vet Diagnostic Investig 22:257-260. https://doi. org/10.1177/104063871002200216

Jia Z, Barakat C, Dong B, Rousseau A (2015) VOCs Destruction by plasma catalyst coupling using AL-KO PURE Air purifier on industrial scale. 19-26

Jiang N, Qiu C, Guo L, Shang K (2017) Post plasma-catalysis of low concentration VOC Over alumina-supported silver catalysts in a surface / packed-bed hybrid discharge reactorhttps://doi.org/10. 1007/s11270-017-3296-6

Joshi AA, Locke BR, Arce P, Finney WC (1995) Formation of hydroxyl radicals, hydrogen peroxide and aqueous electrons by pulsed streamer corona discharge in aqueous solution. J Hazard Mater 41:3-30. https://doi.org/10.1016/0304-3894(94)00099-3

Khaiboullina SF, St Jeor SC (2002) Hantavirus immunology. Viral Immunol 15:609-625. https://doi.org/10.1089/088282402320914 548

Kim J, Jang J (2018) Inactivation of airborne viruses using vacuum ultraviolet photocatalysis for a flow-through indoor air purifier with short irradiation time. Aerosol Sci Technol 52:557-566. https://doi.org/10.1080/02786826.2018.1431386

Kordová T, Scholtz V, Khun J, et al (2018) Inactivation of microbial food contamination of plastic cups using nonthermal plasma and hydrogen peroxide. J Food Qual 2018https://doi.org/10.1155/ 2018/5616437

Lacombe A, Niemira BA, Gurtler JB et al (2017) Nonthermal inactivation of norovirus surrogates on blueberries using atmospheric cold plasma. Food Microbiol 63:1-5. https://doi.org/10.1016/j. fm.2016.10.030

Lee J, Bong C, Lim W et al (2021) Fast and easy disinfection of coronavirus-contaminated face masks using ozone gas produced by a dielectric barrier discharge plasma generator. Environ Sci Technol Lett 8:339-344. https://doi.org/10.1021/acs.estlett.1c00089

$\mathrm{Li} \mathrm{H}, \mathrm{Li} \mathrm{T}, \mathrm{He} \mathrm{S}$, et al (2020) Efficient degradation of antibiotics by non-thermal discharge plasma: Highlight the impacts of molecular structures and degradation pathways. Chem Eng J 395https:// doi.org/10.1016/j.cej.2020.125091

Li R, Cui L, Chen M, Huang Y (2021) Nanomaterials for airborne virus inactivation: a short review. Aerosol Sci Eng 5:1-11. https://doi. org/10.1007/s41810-020-00080-4

Liang Y, Wang ML, Chien CS, et al (2020) Highlight of immune pathogenic response and hematopathologic effect in SARSCoV, MERS-CoV, and SARS-Cov-2 infection. Front Immunol 11https://doi.org/10.3389/fimmu.2020.01022 
Lippi A, Domingues R, Setz C et al (2020) SARS-CoV-2: at the crossroad between aging and neurodegeneration. Mov Disord 35:716720. https://doi.org/10.1002/mds. 28084

Maisey SJ (2012) Air quality in homes: investigating the chemistry of indoor air pollutants through the development of a model tailored with field measurements

Martínez-Montelongo JH, Medina-Ramírez IE, Romo-Lozano Y, Zapien JA (2020) Development of a sustainable photocatalytic process for air purification. Chemosphere 257:127236. https:// doi.org/10.1016/j.chemosphere.2020.127236

Matsumoto Y, Shioji N, Satake T, Sakuma A (1992) Inactivation of microorganisms by pulsed high voltage application. 652-659. https://doi.org/10.1109/ias.1991.178248

McGill F, Griffiths MJ, Solomon T (2017) Viral meningitis: current issues in diagnosis and treatment. Curr Opin Infect Dis 30:248256. https://doi.org/10.1097/QCO.0000000000000355

Michielsen I, Uytdenhouwen Y, Pype J et al (2017) CO2 dissociation in a packed bed DBD reactor: first steps towards a better understanding of plasma catalysis. Chem Eng J 326:477-488. https:// doi.org/10.1016/j.cej.2017.05.177

Mina MJ, Kula T, Leng Y et al (2019) Measles virus infection diminishes preexisting antibodies that offer protection from other pathogens. Viral Immunol 606:599-606

Mohamed H, Nayak G, Rendine N et al (2021) Non-thermal plasma as a novel strategy for treating or preventing viral infection and associated disease. Front Phys 9:1-25. https://doi.org/10.3389/ fphy.2021.683118

Monteil V, Kwon H, Prado P et al (2020) Inhibition of SARS-CoV-2 infections in engineered human tissues using clinical-grade soluble human ACE2. Cell 181:905-913.e7. https://doi.org/10.1016/j. cell.2020.04.004

Moreau M, Orange N, Feuilloley MGJ (2008) Non-thermal plasma technologies: new tools for bio-decontamination. Biotechnol Adv 26:610-617. https://doi.org/10.1016/j.biotechadv.2008.08.001

Moriyama M, Hugentobler WJ, Iwasaki A (2020) Annual review of virology seasonality of respiratory viral infections. Annu Rev Virol 7:1-19. https://doi.org/10.1146/annurev-virol ogy-012420-022445

Morrison C, Atkinson A, Zamyadi A et al (2021) Critical review and research needs of ozone applications related to virus inactivation: potential implications for SARS-CoV-2. Ozone Sci Eng 43:2-20. https://doi.org/10.1080/01919512.2020.1839739

Mrkic B, Pavlovic J, Rülicke T et al (1998) Measles virus spread and pathogenesis in genetically modified mice. J Virol 72:7420 7427. https://doi.org/10.1128/jvi.72.9.7420-7427.1998

Mueller NH, Gilden DH, Cohrs RJ et al (2008) Varicella zoster virus infection: clinical features, molecular pathogenesis of disease, and latency. Neurol Clin 26:675-697. https://doi.org/10.1016/j. ncl.2008.03.011

Mühlemann K (2004) The molecular epidemiology of mumps virus. Infect Genet Evol 4:215-219. https://doi.org/10.1016/j.meegid. 2004.02.003

Muranyi W, Bahr U, Zeier M, Van Der Woude FJ (2005) Hantavirus infection. J Am Soc Nephrol 16:3669-3679. https://doi.org/10. 1681/ASN.2005050561

Mustafa MF, Fu X, Liu Y et al (2018) Volatile organic compounds (VOCs) removal in non-thermal plasma double dielectric barrier discharge reactor. J Hazard Mater 347:317-324. https://doi.org/ 10.1016/j.jhazmat.2018.01.021

Muylaert RL, Bovendorp RS, Sabino-Santos G et al (2019) Hantavirus host assemblages and human disease in the Atlantic Forest. PLoS Negl Trop Dis 13:1-19. https://doi.org/10.1371/journal. pntd.0007655

Myatt TA, Johnston SL, Zuo Z et al (2004) Detection of airborne rhinovirus and its relation to outdoor air supply in office environments.
Am J Respir Crit Care Med 169:1187-1190. https://doi.org/10. 1164/rccm.200306-760oc

Nayak G, Aboubakr HA, Goyal SM, Bruggeman PJ (2018) Reactive species responsible for the inactivation of feline calicivirus by a two-dimensional array of integrated coaxial microhollow dielectric barrier discharges in air. Plasma Process Polym 15:1-32. https://doi.org/10.1002/ppap.201700119

Nikitin N, Petrova E, Trifonova E, Karpova O (2014) Influenza virus aerosols in the air and their infectiousness. Adv Virol 2014https:// doi.org/10.1155/2014/859090

Nöjd J, Tecle T, Samuelsson A, Örvell C (2001) Mumps virus neutralizing antibodies do not protect against reinfection with a heterologous mumps virus genotype. Vaccine 19:1727-1731. https:// doi.org/10.1016/S0264-410X(00)00392-3

Norrby E, Kristensson K (1997) Measles virus in the brain. Brain Res Bull 44:213-220. https://doi.org/10.1016/S0361-9230(97) 00139-1

Olson MR, Axler RP, Hicks RE (2004) Effects of freezing and storage temperature on MS2 viability. J Virol Methods 122:147-152. https://doi.org/10.1016/j.jviromet.2004.08.010

Parkkonen P, Hyöty H, Koskinen L, Leinikki P (1992) Mumps virus infects Beta cells in human fetal islet cell cultures upregulating the expression of HLA class I molecules. Diabetologia 35:63-69. https://doi.org/10.1007/BF00400853

Peate I (1999) Meningitis: causes, symptoms and signs and nursing management. Br J Nurs 8:1290-1296. https://doi.org/10.12968/ bjon.1999.8.19.1290

Pinard L, Ayoub N, Batiot-Dupeyrat C (2019) Regeneration of a coked zeolite via nonthermal plasma process: a parametric study. Plasma Chem Plasma Process. https://doi.org/10.1007/ s11090-019-09972-x

Prussin AJ, Garcia EB, Marr LC (2015) Total concentrations of virus and bacteria in indoor and outdoor air. Environ Sci Technol Lett 2:84-88. https://doi.org/10.1021/acs.estlett.5b00050

Puligundla P, Mok C (2016) Non-thermal plasmas (NTPs) for inactivation of viruses in abiotic environment. Res J Biotechnol 11:91-96

Reuter D, Schneider-Schaulies J (2010) Measles virus infection of the CNS: human disease, animal models, and approaches to therapy. Med Microbiol Immunol 199:261-271. https://doi.org/10.1007/ s00430-010-0153-2

Rtimi S, Kiwi J (2021) Update on interfacial charge transfer (IFTC) processes on films inactivating viruses/bacteria under visible light: mechanistic considerations and critical issues. Catalysts 11:1-22. https://doi.org/10.3390/catal11020201

Sakudo A, Misawa T, Shimizu N, Imanishi Y (2014) N2 gas plasma inactivates influenza virus mediated by oxidative stress. Front Biosci - Elit 6 E:69-79. https://doi.org/10.2741/e692

Sakudo A, Toyokawa Y, Imanishi Y (2016) Nitrogen gas plasma generated by a static induction thyristor as a pulsed power supply inactivates adenovirus. PLoS ONE 11:1-17. https://doi.org/10. 1371/journal.pone.0157922

Sakudo A, Toyokawa Y, Imanishi Y, Murakami T (2017) Crucial roles of reactive chemical species in modification of respiratory syncytial virus by nitrogen gas plasma. Mater Sci Eng C 74:131-136. https://doi.org/10.1016/j.msec.2017.02.007

Sauerbrei A (2016) Diagnosis, antiviral therapy, and prophylaxis of varicella-zoster virus infections. Eur J Clin Microbiol Infect Dis 35:723-734. https://doi.org/10.1007/s10096-016-2605-0

Schiappacasse C, Peng P, Zhou N et al (2020) inactivation of aerosolized newcastle disease virus with non-thermal. Plasma. 36:55-60

Schmidt H, Cohrs S, Heinemann T et al (2006) Sleep disorders are long-term sequelae of both bacterial and viral meningitis. J Neurol Neurosurg Psychiatry 77:554-558. https://doi.org/10.1136/ jnnp.2005.071142 
Schmidt M, Jo I (2015) Non-thermal plasma based decomposition of volatile organic compounds in industrial exhaust gases. 3745-3754. https://doi.org/10.1007/s13762-015-0814-1

Schoenbach KH, Joshi RP, Stark RH et al (2000) Bacterial decontamination of liquids with pulsed electric fields. IEEE Trans Dielectr Electr Insul 7:637-645. https://doi.org/10.1109/94. 879359

Schoenbach KH, Peterkin FE, Alden RW, Beebe SJ (1997) The effect of pulsed electric fields on biological cells: experiments and applications. IEEE Trans Plasma Sci 25:284-292. https://doi. org/10.1109/27.602501

Scholtz V, Pazlarova J, Souskova H et al (2015) Nonthermal plasma - a tool for decontamination and disinfection. Biotechnol Adv 33:1108-1119. https://doi.org/10.1016/j.biotechadv.2015.01. 002

Shimizu K, Oda T (1999) Denox process in flue gas combined with nonthermal plasma and catalyst. IEEE Trans Ind Appl 35:13111317. https://doi.org/10.1109/ias.1997.626324

Su X, Tian Y, Zhou H et al (2018) Inactivation efficacy of nonthermal plasmaactivated solutions against Newcastle disease virus. Appl Environ Microbiol 84:1-12. https://doi.org/10.1128/AEM. 02836-17

Sun YH, Zhou YX, Jin MJ et al (2005) New prototype of underwater sound source based on the pulsed corona discharge. J Electrostat 63:969-975. https://doi.org/10.1016/j.elstat.2005.03.070

Šnka P (2001) Pulse electrical discharges in water and their applications. Phys Plasmas 8:2587-2594. https://doi.org/10.1063/1. 1356742

Tang S, Yuan D, Rao Y et al (2018) Persulfate activation in gas phase surface discharge plasma for synergetic removal of antibiotic in water. Chem Eng J 337:446-454. https://doi.org/10.1016/j.cej. 2017.12.117

Tellier R (2006) Review of aerosol transmission of influenza A virus. Emerg Infect Dis 12:1657-1662. https://doi.org/10.3201/eid12 11.060426

Tellier R (2009) Aerosol transmission of influenza A virus: a review of new studies. J R Soc Interface 6https://doi.org/10.1098/rsif. 2009.0302.focus

Tersago K, Verhagen R, Servais A et al (2009) Hantavirus disease (nephropathia epidemica) in Belgium: effects of tree seed production and climate. Epidemiol Infect 137:250-256. https://doi. org/10.1017/S0950268808000940

Tersago K, Verhagen R, Vapalahti O et al (2011) Hantavirus outbreak in Western Europe: reservoir host infection dynamics related to human disease patterns. Epidemiol Infect 139:381-390. https:// doi.org/10.1017/S0950268810000956

Thibaut HJ, Lacroix C, De Palma AM et al (2016) Toward antiviral therapy/prophylaxis for rhinovirus-induced exacerbations of chronic obstructive pulmonary disease: challenges, opportunities, and strategies. Rev Med Virol 26:21-33. https://doi.org/10. 1002/rmv.1856

To Kelvin KW, Yip CCY, Yuen KY (2017) Rhinovirus - from bench to bedside. J Formos Med Assoc 116:496-504. https://doi.org/ 10.1016/j.jfma.2017.04.009

Tregoning JS, Schwarze J (2010) Respiratory viral infections in infants: causes, clinical symptoms, virology, and immunology. Clin Microbiol Rev 23:74-98. https://doi.org/10.1128/CMR.00032-09

Tung-Thompson G, Libera DA, Koch KL et al (2015) Aerosolization of a human norovirus surrogate, bacteriophage MS2, during simulated vomiting. PLoS ONE 10:1-13. https://doi.org/10.1371/ journal.pone.0134277

Tuppeny M (2013) Viral meningitis and encephalitis. Crit Care Nurs Clin North Am 25:363-380. https://doi.org/10.1016/j.ccell.2013. 04.003

Turner RB (2007) Rhinovirus: More than just a common cold virus. J Infect Dis 195:765-766. https://doi.org/10.1086/511829
U.S. Environmental Protection Agency Green Building Workgroup (2009) Buildings and their Impact on the Environment: A Statistical Summary

Uytdenhouwen Y, Van Alphen S, Michielsen I et al (2018) A packedbed DBD micro plasma reactor for $\mathrm{CO} 2$ dissociation: Does size matter? Chem Eng J 348:557-568. https://doi.org/10.1016/j.cej. 2018.04.210

Vohra A, Goswami DY, Deshpande DA, Block SS (2006) Enhanced photocatalytic disinfection of indoor air. Appl Catal B Environ 64:57-65. https://doi.org/10.1016/j.apcatb.2005.10.025

Volotskova O, Dubrovsky L, Keidar M, Bukrinsky M (2016) Cold atmospheric plasma inhibits HIV-1 replication in macrophages by targeting both the virus and the cells. PLoS ONE 11:1-9. https://doi.org/10.1371/journal.pone.0165322

Wang CC, Prather KA, Sznitman J, et al (2021) Airborne transmission of respiratory viruses. Science (80-) 373:. https://doi.org/ 10.1126/science.abd9149

Wang G, Zhu R, Yang L et al (2016) Non-thermal plasma for inactivated-vaccine preparation. Vaccine 34:1126-1132. https://doi. org/10.1016/j.vaccine.2015.10.099

Wang H, Li J, Quan X (2006) Decoloration of azo dye by a multineedle-to-plate high-voltage pulsed corona discharge system in water. J Electrostat 64:416-421. https://doi.org/10.1016/j.elstat. 2005.11.004

Wang H, Li J, Quan X, Wu Y (2008) Enhanced generation of oxidative species and phenol degradation in a discharge plasma system coupled with $\mathrm{TiO} 2$ photocatalysis. Appl Catal B Environ 83:72-77. https://doi.org/10.1016/j.apcatb.2008.02.004

Wang T, Jia H, Guo X et al (2018) Evaluation of the potential of dimethyl phthalate degradation in aqueous using sodium percarbonate activated by discharge plasma. Chem Eng J 346:65-76. https:// doi.org/10.1016/j.cej.2018.04.024

World Health Organization (2000) The right to healthy indoor air : report on a WHO meeting, Bilthoven, The Netherlands. 15. https://apps.who.int/iris/handle/10665/108327

World Health Organization (2019) Global influenza strategy 20192030. Geneva: 2019. Licence: CC BY-NC-SA 3.0 IGO.Cataloguing-in-Publication (CIP) data.

Wu Y, Liang Y, Wei K et al (2015) MS2 virus inactivation by atmospheric-pressure cold plasma using different gas carriers and power levels. Appl Environ Microbiol 81:996-1002. https://doi. org/10.1128/AEM.03322-14

Xia T, Kleinheksel A, Lee EM, et al (2019) Inactivation of airborne viruses using a packed bed non-thermal plasma reactor. J Phys D Appl Phys 52https://doi.org/10.1088/1361-6463/ab1466

Xia T, Yang M, Marabella I et al (2020) Inactivation of airborne porcine reproductive and respiratory syndrome virus (PRRSv) by a packed bed dielectric barrier discharge non-thermal plasma. $\mathrm{J}$ Hazard Mater 393:1-30. https://doi.org/10.1016/j.jhazmat.2020. 122266

Xiao Wu, Nethery RC, Benjamin Sabath M, Danielle Braun FD (2020) Exposure to air pollution and COVID-19 mortality in the United States: a nationwide cross-sectional study. Harvard Univ. https:// doi.org/10.1101/2020.04.05.20054502

Xue J, Chen L, Wang H (2008) Degradation mechanism of Alizarin Red in hybrid gas-liquid phase dielectric barrier discharge plasmas: experimental and theoretical examination. Chem Eng J 138:120-127. https://doi.org/10.1016/j.cej.2007.05.055

Yamashiro R, Misawa T, Sakudo A (2018) Key role of singlet oxygen and peroxynitrite in viral RNA damage during virucidal effect of plasma torch on feline calicivirus. Sci Rep 8:1-13. https://doi. org/10.1038/s41598-018-36779-1

Yardimci O, Setlow P (2010) Plasma sterilization: opportunities and microbial assessment strategies in medical device manufacturing. IEEE Trans Plasma Sci 38:973-981. https://doi.org/10.1109/ TPS.2010.2041674 
Yasuda H, Miura T, Kurita H et al (2010) Biological evaluation of DNA damage in bacteriophages inactivated by atmospheric pressure cold plasma. Plasma Process Polym 7:301-308. https://doi. org/10.1002/ppap.200900088

Zhang Y, Geng X, Tan Y et al (2020) New understanding of the damage of SARS-CoV-2 infection outside the respiratory system. Biomed Pharmacother 127:110195. https://doi.org/10.1016/j. biopha.2020.110195

Zhang Z, Gamage J (2010) Applications of photocatalytic disinfection. Int J Photoenergy 2010https://doi.org/10.1155/2010/764870

Zhou R, Zhou R, Zhang X et al (2016) Synergistic effect of atmospheric-pressure plasma and $\mathrm{TiO} 2$ Photocatalysis on inactivation of escherichia coli cells in aqueous media. Sci Rep 6:1-10. https://doi.org/10.1038/srep39552

Zimmermann JL, Dumler K, Shimizu T, et al (2011) Effects of cold atmospheric plasmas on adenoviruses in solution. J Phys D Appl Phys 44https://doi.org/10.1088/0022-3727/44/50/505201

Publisher's Note Springer Nature remains neutral with regard to jurisdictional claims in published maps and institutional affiliations. 